\title{
Most used ICT methodologies for student learning in Erasmus+ projects related to eLearning
}

\author{
María Goretti Alonso de Castro \\ Education in the Knowledge Society \\ $\mathrm{PhD}$ (GRIAL Research Group) \\ University of Salamanca \\ 37008 Salamanca, Spain \\ https://orcid.org/0000-0003-4745-9364 \\ malonsca@gmail.com
}

\author{
Francisco José García-Peñalvo \\ GRIAL Research Group \\ Computer Science Department \\ Research Institute for Educational \\ Sciences \\ University of Salamanca \\ 37008 Salamanca, Spain \\ https://orcid.org/0000-0001-9987-5584 \\ fgarcia@usal.es
}

\begin{abstract}
European projects provide very valuable information on the methodologies that are being used at an educational level in different countries of the European Union and associated countries, for this reason this article focuses on how students' learning is approached through technologies within European projects related to the field of eLearning. The information provided is the result of the research that is being carried out on the PhD work within the GRIAL group of the University of Salamanca. The results show a greater representation of projects from the school and VET sectors and that the predominant ICT tools used by the students are those connected to office automation management, basic skills as well as the use of network resources and platforms for collaboration, and digital educational games, with small differences between educational fields.
\end{abstract}

Keywords—Learning, ICT, students, European projects

\section{INTRODUCTION}

We live in a changing society in which it is necessary to equip citizens with sufficient skills that allow them to adapt to emerging needs that arise and to the constant evolution of jobs. On this path towards the training of citizens to achieve wellprepared people to face the challenges that emerge in this environment, teaching and training is the key, for which it is necessary to have a good teachers' professional development and students who receive quality education [1].

All these social changes have been shown more, if possible, with the irruption of the COVID-19 pandemic [2] that has promoted digitization in all areas $[3,4]$. In this sense numerous publications have been made on how to adapt to new situations from different perspectives. This is the case, among others, of F. J. García-Peñalvo and A. Corell [5] analyzing digital transformation of teaching or F. J. GarcíaPeñalvo et al. [6] proposing a guide of recommendations to help teachers and universities in the evaluation process due to COVID-19, as well as the OECD that has extracted some lessons for Education from COVID-19 [7].

The European Union is not oblivious to these needs and therefore promotes the implementation of European educational projects with funding to improve education systems and teaching-learning processes [8]. Through the Erasmus + programme [9], as well as previous programmes, numerous educational projects have been developed in which new methodologies are implemented and explored to achieve the desired improvement in training.

Consequently, from the analysis of the projects developed in the aforementioned programme, numerous teaching practices can be extracted that have been successful and can be a source of inspiration and learning for future projects [10] and that is why the $\mathrm{PhD}$ work "Methodological guide for the successful use of digital technologies in education" [11-13] began.

Through this research work, we are looking for the most outstanding educational practices that have worked adequately in a group of projects that have a relationship with eLearning [14, 15] and Information and Communications Technologies (ICT). The results obtained so far in those aspects related to the methodologies used with the students are analyzed in the following sections, in which the research methodology, the response rate, the main results obtained, and the conclusions are exposed.

\section{METHODOLOGY FOR THE RESEARCH}

This $\mathrm{PhD}$ research follows the guidelines specified in systematic reviews of research projects $[16,17]$. This type of analysis of projects provides an overview of the current trends and identify the lacks and opportunities to define new advances in the area of research. Besides, they provide an opportunity to compare between closed projects and get a picture of the evolution of technological ecosystems in the field.

Moreover, those guidelines provide a research method to analyze with a systematic procedure project databases and mapping projects. The procedure implies four stages: study definition, screening definition, projects' selection, and analysis. At this stage the three first steps have been finished as well as the analysis of contacts, summaries, and outputs of the projects. Additionally, we have been able to get more data regarding the reasons for their success throughout a survey.

Presently we are undertaking the analysis phase through the survey designed to collect more detailed information on key aspects of the projects in relation to their degree of success and the ICT tools used.

\section{A. Sections of the survey}

The design of the survey has been based on theories of questionnaire design from different publications in which there are a definition of the types of open or closed questions, the methodology, the way of writing the questions in a clear language grouped and in order, a recommended number of questions between 20 and 30 and the time devoted to fill in the survey between a quarter of an hour and one hour most [1820]. Different models have been reviewed to try to elaborate the survey, which has finally resulted in a maximum length of 
21 questions with dichotomous and open sub-questions for an average time of 20 minutes.

The survey is divided into 6 sections:

- The first one is aimed at identifying the project with the sole purpose of being able to contact afterwards for an interview.

- The second one is aimed at global aspects that allow determining the factors that have favored the projects being classified as good practical or success story.

- The third section has to do with the students and the ICT tools used in the teaching processes with them.

- The fourth is focused on collecting information related to teachers and ICT.

- The fifth is devoted to other aspects of the project related to the use and sustainability of the results achieved from the project, among other things.

- The final section is oriented to collect the main conclusions.

This paper is focus on the results obtained with the third section of the survey.

\section{B. Questions regarding students learning an ICT in Erasmus + projects}

Regarding the design of the questions for students and ICT the questionnaires of International Computer and Information Literacy Study (ICLS) [21] and the OECD PISA Global Crises Questionnaire Module [22] have been a source of inspiration. As a result of that, the questions included in the questionnaire, reason for this article and related to the approach of students and ICT in the Erasmus + projects analyzed, are those presented on the table I. There are three questions: one related to the students' educational level, another one as regards as the ICT tools used within the projects and the last one in relation to the ICT devices employed.

\begin{tabular}{|c|c|c|}
\hline \multirow{2}{*}{ N. } & \multicolumn{2}{|r|}{ Questions } \\
\hline & Question & Option \\
\hline 1 & $\begin{array}{l}\text { What level are the } \\
\text { students who have } \\
\text { participated in the } \\
\text { project? (select all } \\
\text { that apply) }\end{array}$ & $\begin{array}{l}\text { Q0006[SQ001] Early Childhood Education } \\
\text { Q0006[SQ002] Primary Education } \\
\text { Q0006[SQ003] Secondary Education } \\
\text { Q0006[SQ004] Baccalaureate } \\
\text { Q0006[SQ005] Vocational Education and } \\
\text { Training } \\
\text { Q0006[SQ006] University } \\
\text { Q0006[SQ007] Adult Education } \\
\text { Q0006[SQ008] None, no work with students } \\
\text { in the project } \\
\text { Q0006[SQ009] Other }\end{array}$ \\
\hline 2 & $\begin{array}{l}\text { What ICT tools } \\
\text { does the project } \\
\text { use to improve } \\
\text { student learning? } \\
\text { (select all that } \\
\text { apply) }\end{array}$ & $\begin{array}{l}\text { Q0007[SQ001] Development of basic digital } \\
\text { skills (for example, software installation, } \\
\text { Internet use, email, word processing, } \\
\text { spreadsheets, graphics, file transfer, etc.) } \\
\text { Q0007[SQ002] Making presentations } \\
\text { (Prezzy, Genially, Microsoft PowerPoint, } \\
\text { LibreOffice Impress, etc.) } \\
\text { Q0007[SQ003] Development of skills in the } \\
\text { use of ICT for collaboration with others and } \\
\text { to increase and improve student learning } \\
\text { (Google Docs, OneNote, Dropbox, box, } \\
\text { Zoho, Padlet, forums, wikis, etc.) }\end{array}$ \\
\hline
\end{tabular}

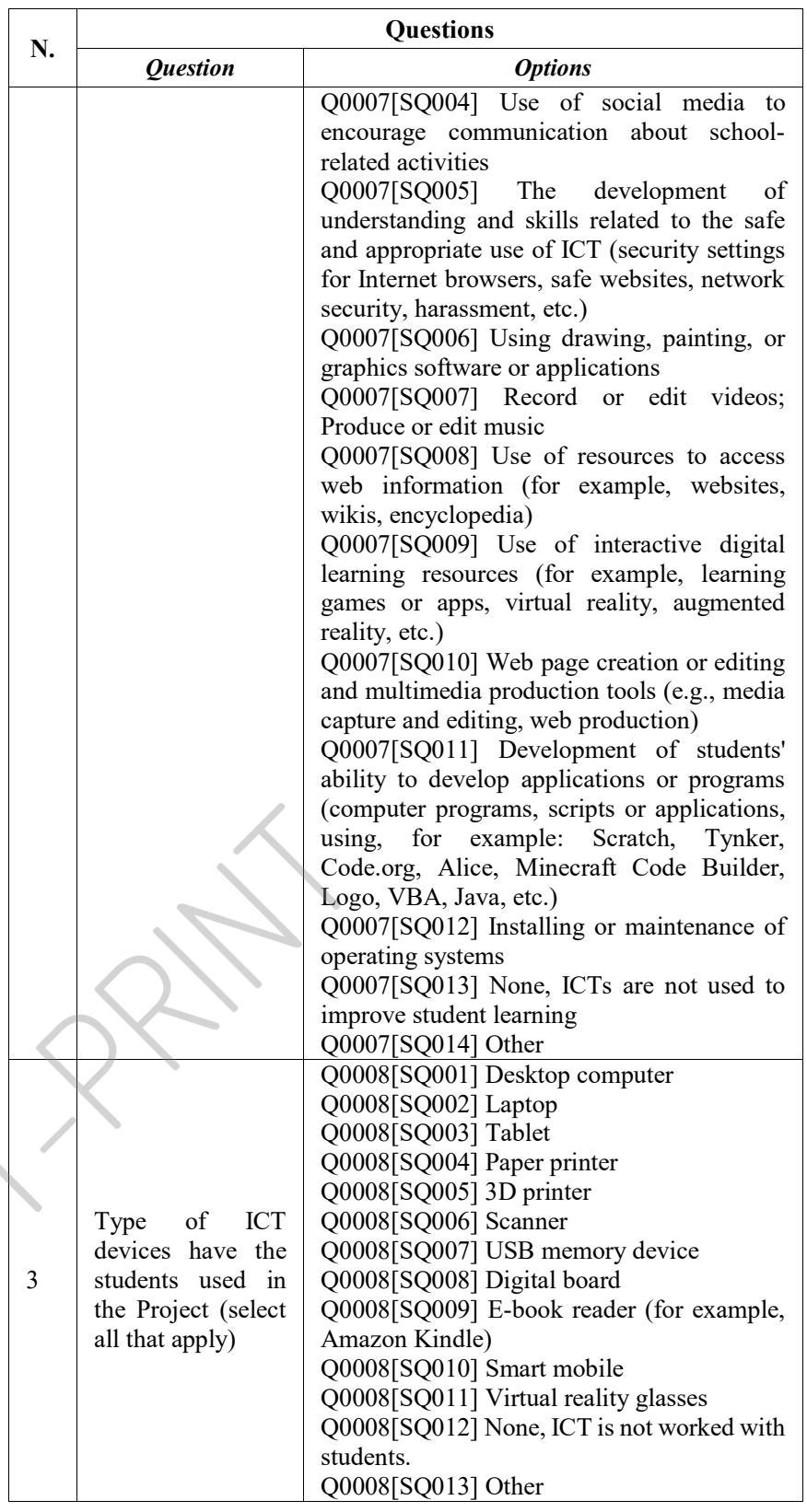

\section{RESPONSE RATE}

One of the aspects that must be considered when analyzing the data is the response rate with respect to the selected sample of projects.

In order to carry out the analysis, all the projects that met a series of requirements were chosen $[12,13]$ :

- Linked with the term eLearning.

- Labelled as good practice or success story.

- Key actions KA1 and KA2: actions with more than 50 eLearning projects.

- Involving educational centers, that are an important element for analyzing the improvement in the learning process.

After that, the contact information was compiled using the data available on the Erasmus+ Results Platform [10] or on the coordinators and/or partners websites. Afterwards, the questionnaire was sent to all those contacts that matched the criteria. 
The starting point was 1,144 projects that matched the first three requirements previously mentioned, of which 256 did not have any educational centers and with 39 that was not possible to find an email. Hence the total amount of institutions contacted were 849 of which 187 have completed the questionnaire satisfactorily. Therefore, the response rate has been of $22 \%$.

\section{MAIN FINDINGS ON THE USE OF ICT WITH STUDENTS}

From the data collected with the survey, the information that is exposed in the following sections can be extracted.

\section{A. Educational levels most represented in the completed surveys}

The educational sectors most represented in the projects analyzed have been Secondary Education (41\%) and vocational education and training $(35 \%)$, followed by University training $(24 \%)$ and that of adults $(20 \%)$, as it can be seen in Fig. 1. These results match with the initial distribution of projects, in which the predominant sector also corresponded to School Education (Early Childhood Education, Primary Education, Secondary Education and Baccalaureate) followed by Vocational Education and Training [12, 13].

These educational sectors are also the ones that can provide more information to be able to propose them as a model or example of the successful use of ICT methodologies by students for future projects, an objective pursued with this research work.

Fig. 1. Use of ICT devices by the students within Erasmus + projects

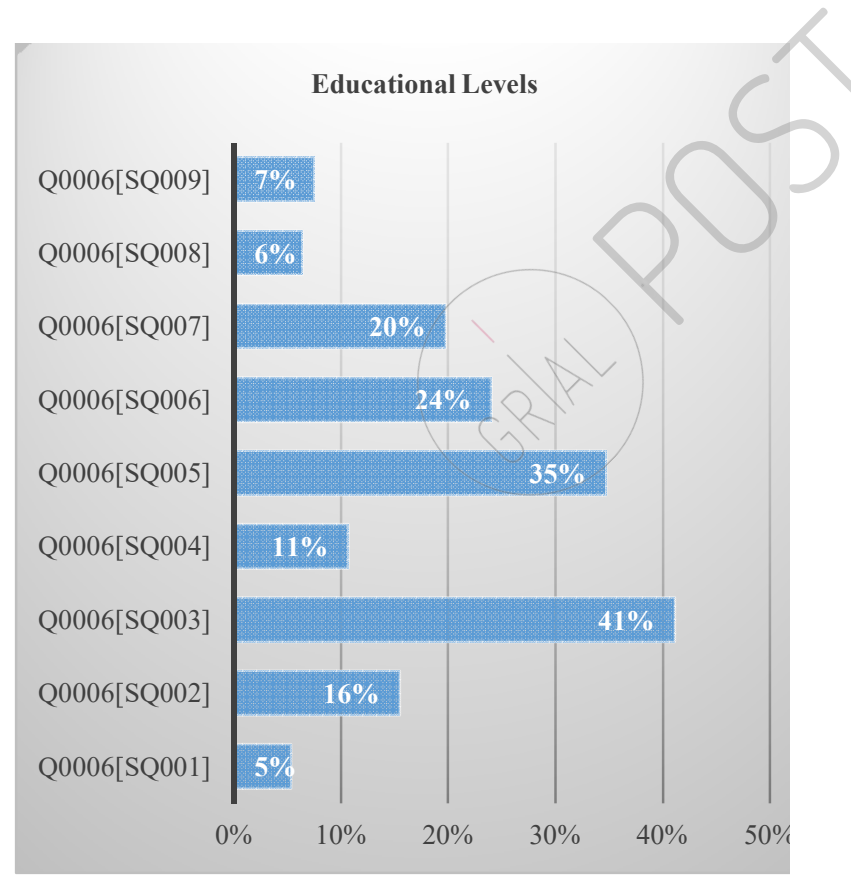

Fig. 1 shows that $6 \%$ of the projects analyzed did not work with students and the $7 \%$ indicated other options that were not included in the survey.

\section{B. Most used ICT Tools}

The use of digital tools by students in this type of project is an element of interest to learn more about the trends in teaching for the improvement of digital skills, increasingly necessary in the current environment subject to constant change.

In today's society, the use of networks and the processing of digital information increasingly predominate, and it is necessary to have competent students to be able to discriminate what is fact from what is fiction, as well as being able to use the tools to present and analyze the data they handle in their daily activities.

For this reason, one of the questions that have been considered relevant for the survey has been to know which digital tools are most frequently used in the Erasmus + projects analyzed. In Fig. 2 are shown the results obtained from the survey.

Fig. 2. Use of ICT tools by the students within Erasmus+ projects

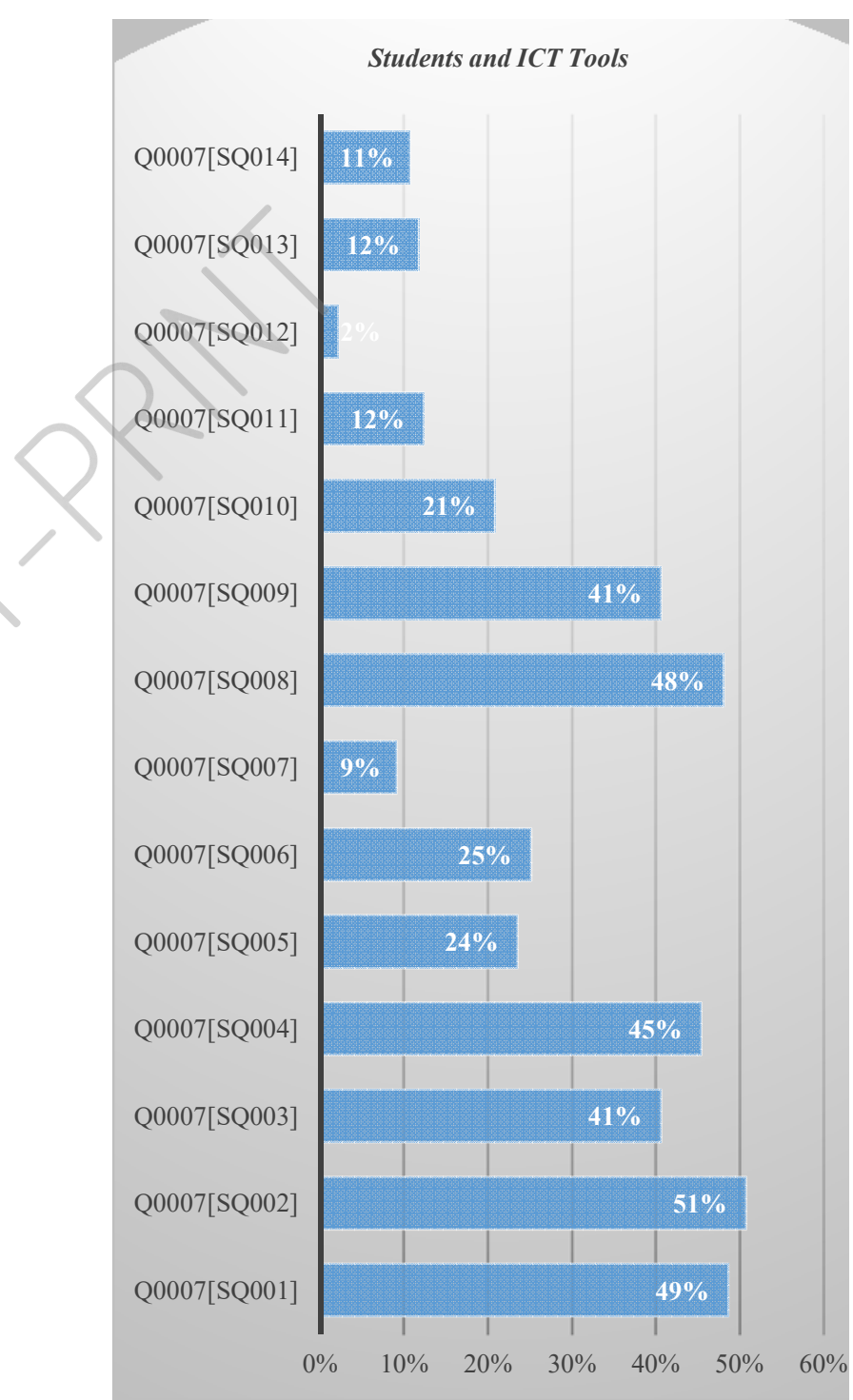

The 6 most prominent digital tools used are:

1) Making presentations (Prezzy, Genially, Microsoft PowerPoint, LibreOffice Impress, etc.) (51\%).

2) Development of basic digital skills (for example, software installation, Internet use, email, word processing, spreadsheets, graphics, file transfer, etc.) (49\%). 
3) Use of resources to access web information (for

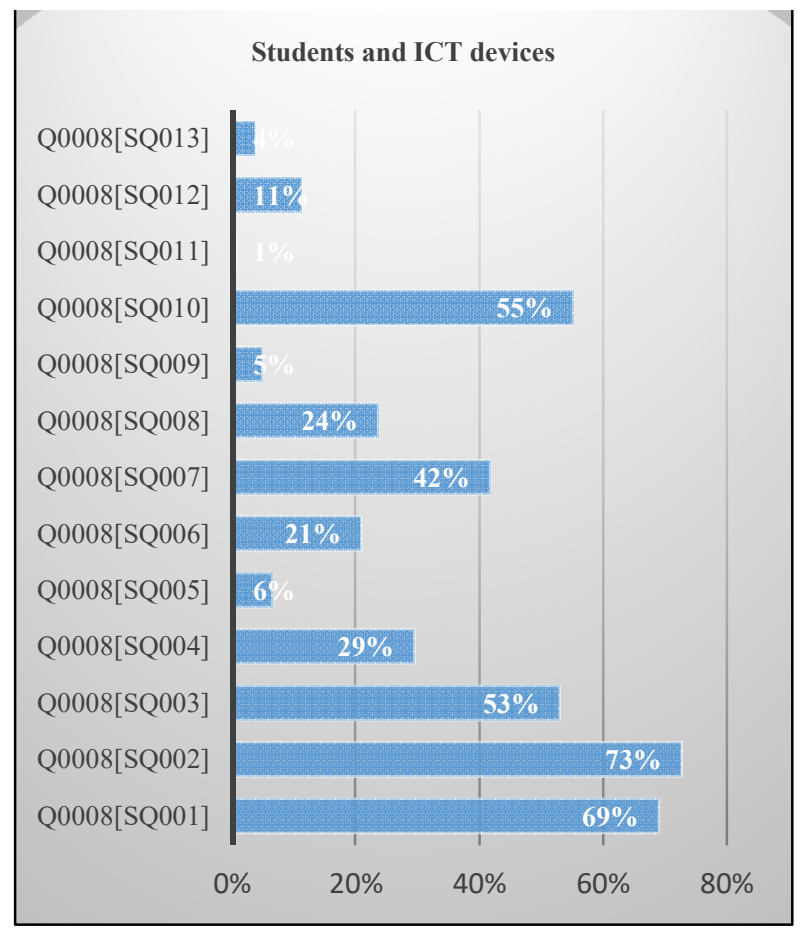

example, websites, wikis, encyclopedia) (48\%).

4) Use of social media to encourage communication about school-related activities (45\%).

5) Development of skills in the use of ICT for collaboration with others and to increase and improve student learning (Google Docs, OneNote, Dropbox, box, Zoho, Padlet, forums, wikis, etc.) (41\%).

6) Use of interactive digital learning resources (for example, learning games or apps, virtual reality, augmented reality, etc.) $(41 \%)$.

It is observed that the most outstanding ones have to do with office automation management and basic skills as well as the use of network resources and platforms for collaboration. Tools related to digital educational games also stand out.

Those that are used less frequently are those that require a more professional level of knowledge, such as installing or maintenance of operating systems, development of students' ability to develop applications or programs or web page creation or editing.

\section{Most prominent ICT devices}

Another aspect, that was considered of interest in order to observe some of the teaching practices with students in the Erasmus+ projects analyzed, is what type of ICT devices are the most used.

Having a good understanding of existing devices and how to use them safely and in an agile way is important for the daily life and future world of work of students. As indicated in the paper Educational projects based on mobile learning "statistics show that smartphones and tablets are growing in number, making learning increasingly mobile and easier for the average student" [23], so is vital to equip our students with the skills for using this technology efficiently.
The use of digital devices provides information on the skills that students are developing in the teaching process, and Fig. 3 shows what are the most prominent ones.

Fig. 3. Use of ICT devices by the students within Erasmus + projects

As can be seen in Fig. 3, the most common devices used within the Erasmus + projects analyzed are:

1) Laptop (73\%)

2) Desktop computer (69\%)

3) Smart mobile (59\%)

4) Tablet $(53 \%)$

5) USB memory device (42\%)

The less popular ones are virtual reality glasses, e-book reader and 3D printer. This may be due to the fact that these devices are not so common in educational centers.

However, it is very significant that the most used devices are either portable or desktop computers followed by smart phones and tablets because those are the most used also in the work environment and a good use of them will help to have well-prepared students for their future jobs.

\section{Differencies between educational fields}

In previous sections, the global results have been reviewed in relation to the ICT tools and devices used by the students in the projects that responded to the survey, but it is also interesting to compare the differences according to the educational level of the students. Knowing the trends according to the educational sector can help in the definition of new projects or lines of research. Hence, this section presents a comparison of the results obtained according to the educational sectors.

As regards to the ICT tools we find the differences presented in Table II. Only School Education, Vocational Education and Training (VET), Higher Education and Adult Education are being included on the comparison.

TABLE II. STUDENTS AND ICT TOOLS BY EDUCATIONAL FIELD

\begin{tabular}{|c|c|c|c|c|}
\hline \multirow{2}{*}{$\begin{array}{l}\text { Question } \\
\text { code }\end{array}$} & \multicolumn{4}{|c|}{ Educational Field } \\
\hline & $\begin{array}{c}\text { School } \\
\text { Education }\end{array}$ & VET & $\begin{array}{c}\text { Higher } \\
\text { Education }\end{array}$ & $\begin{array}{c}\text { Adult } \\
\text { Education }\end{array}$ \\
\hline $\begin{array}{l}\text { Q0007 } \\
\text { [SQ001] }\end{array}$ & $65 \%$ & $38 \%$ & $29 \%$ & $35 \%$ \\
\hline $\begin{array}{l}\text { Q0007 } \\
\text { [SQ002] }\end{array}$ & $74 \%$ & $26 \%$ & $35 \%$ & $35 \%$ \\
\hline $\begin{array}{l}\text { Q0007 } \\
\text { [SQ003] }\end{array}$ & $58 \%$ & $33 \%$ & $12 \%$ & $19 \%$ \\
\hline $\begin{array}{l}\text { Q0007 } \\
{[S Q 004]}\end{array}$ & $58 \%$ & $31 \%$ & $24 \%$ & $42 \%$ \\
\hline $\begin{array}{l}\text { Q0007 } \\
\text { [SQ005] }\end{array}$ & $38 \%$ & $14 \%$ & $12 \%$ & $8 \%$ \\
\hline $\begin{array}{l}\text { Q0007 } \\
\text { [SQ006] }\end{array}$ & $39 \%$ & $17 \%$ & $12 \%$ & $0 \%$ \\
\hline $\begin{array}{l}\text { Q0007 } \\
{[S Q 007]}\end{array}$ & $16 \%$ & $2 \%$ & $6 \%$ & $0 \%$ \\
\hline $\begin{array}{l}\text { Q0007 } \\
\text { [SQ008] }\end{array}$ & $59 \%$ & $36 \%$ & $47 \%$ & $46 \%$ \\
\hline $\begin{array}{l}\text { Q0007 } \\
\text { [SQ009] }\end{array}$ & $44 \%$ & $45 \%$ & $35 \%$ & $27 \%$ \\
\hline $\begin{array}{l}\text { Q0007 } \\
\text { [SQ010] }\end{array}$ & $34 \%$ & $10 \%$ & $0 \%$ & $8 \%$ \\
\hline $\begin{array}{l}\mathrm{Q} 0007 \\
{[\mathrm{SQ} 011]}\end{array}$ & $16 \%$ & $7 \%$ & $6 \%$ & $8 \%$ \\
\hline $\begin{array}{l}\text { Q0007 } \\
\text { [SQ012] }\end{array}$ & $1 \%$ & $5 \%$ & $0 \%$ & $4 \%$ \\
\hline
\end{tabular}




\begin{tabular}{|l|l|l|l|c|}
\hline \multirow{2}{*}{$\begin{array}{c}\text { Question } \\
\text { code }\end{array}$} & \multicolumn{4}{|c|}{ Educational Field } \\
\cline { 2 - 5 } & $\begin{array}{c}\text { School } \\
\text { Education }\end{array}$ & VET & $\begin{array}{c}\text { Higher } \\
\text { Education }\end{array}$ & $\begin{array}{c}\text { Adult } \\
\text { Education }\end{array}$ \\
\hline $\begin{array}{c}\text { Q0007 } \\
\text { [SQ013] }\end{array}$ & $6 \%$ & $14 \%$ & $18 \%$ & $23 \%$ \\
\hline
\end{tabular}

In the data reflected in Table II, it is detected that there are differences in which are the most used ICT tools according to educational fields. In the case of the school field, it is in line with the results obtained globally in order of importance in the use of the tools, while in the other fields there are some changes that are highlighted below:

- In the VET field the three most important tools are: use of interactive digital learning resources (for example, learning games or apps, virtual reality, augmented reality, etc.), development of basic digital skills (for example, software installation, Internet use, email, word processing, spreadsheets, graphics, file transfer, etc.) and use of resources to access web information (for example, websites, wikis, encyclopedia).

- In Higher Education stand out the use of resources to access web information (for example, websites, wikis, encyclopedia), making presentations (Prezzy, Genially, Microsoft PowerPoint, LibreOffice Impress, etc.) and use of interactive digital learning resources (for example, learning games or apps, virtual reality, augmented reality, etc.).

- In Adult Education the predominant ones are the use of resources to access web information (for example, websites, wikis, encyclopedia), making presentations (Prezzy, Genially, Microsoft PowerPoint, LibreOffice Impress, etc.) and development of basic digital skills (for example, software installation, Internet use, email, word processing, spreadsheets, graphics, file transfer, etc.).

Actually, they are small variations in terms of the importance given to them in each field, but it is clear that interests, needs and concerns change according to educational level.

In relation with the behavior in the case of the use of ICT devices the results by educational field are shown in Table III.

TABLE III. STUDENTS AND ICT DEVICES BY EDUCATIONAL FIELD

\begin{tabular}{|c|c|c|c|c|}
\hline \multirow{2}{*}{$\begin{array}{l}\text { Question } \\
\text { code }\end{array}$} & \multicolumn{4}{|c|}{ Educational Field } \\
\hline & $\begin{array}{c}\text { School } \\
\text { Education }\end{array}$ & $V E T$ & $\begin{array}{c}\text { Higher } \\
\text { Education }\end{array}$ & $\begin{array}{c}\text { Adult } \\
\text { Education }\end{array}$ \\
\hline $\begin{array}{l}\text { Q0008 } \\
{[S Q 001]}\end{array}$ & $65 \%$ & $38 \%$ & $29 \%$ & $35 \%$ \\
\hline $\begin{array}{l}\text { Q0008 } \\
\text { [SQ002] }\end{array}$ & $72 \%$ & $83 \%$ & $71 \%$ & $46 \%$ \\
\hline $\begin{array}{l}\text { Q0008 } \\
\text { [SQ003] }\end{array}$ & $68 \%$ & $90 \%$ & $71 \%$ & $62 \%$ \\
\hline $\begin{array}{l}\mathrm{Q} 0008 \\
{[\mathrm{SQ} 004]}\end{array}$ & $53 \%$ & $67 \%$ & $41 \%$ & $38 \%$ \\
\hline $\begin{array}{l}\text { Q0008 } \\
\text { [SQ005] }\end{array}$ & $44 \%$ & $14 \%$ & $12 \%$ & $19 \%$ \\
\hline $\begin{array}{l}\text { Q0008 } \\
\text { [SQ006] }\end{array}$ & $9 \%$ & $5 \%$ & $6 \%$ & $4 \%$ \\
\hline $\begin{array}{l}\text { Q0008 } \\
\text { [SQ007] }\end{array}$ & $33 \%$ & $10 \%$ & $18 \%$ & $12 \%$ \\
\hline $\begin{array}{l}\text { Q0008 } \\
\text { [SQ008] }\end{array}$ & $58 \%$ & $29 \%$ & $24 \%$ & $23 \%$ \\
\hline $\begin{array}{l}\text { Q0008 } \\
\text { [SQ009] }\end{array}$ & $42 \%$ & $7 \%$ & $18 \%$ & $4 \%$ \\
\hline
\end{tabular}

\begin{tabular}{|l|l|l|l|l|}
\hline \multirow{2}{*}{$\begin{array}{c}\text { Question } \\
\text { code }\end{array}$} & \multicolumn{4}{|c|}{ Educational Field } \\
\cline { 2 - 5 } & $\begin{array}{c}\text { School } \\
\text { Education }\end{array}$ & VET & $\begin{array}{c}\text { Higher } \\
\text { Education }\end{array}$ & $\begin{array}{c}\text { Adult } \\
\text { Education }\end{array}$ \\
\hline $\begin{array}{l}\text { Q0007 } \\
{[S Q 010]}\end{array}$ & $7 \%$ & $2 \%$ & $0 \%$ & $8 \%$ \\
\hline $\begin{array}{l}\text { Q0008 } \\
{[S Q 011]}\end{array}$ & $63 \%$ & $60 \%$ & $35 \%$ & $38 \%$ \\
\hline $\begin{array}{l}\text { Q0008 } \\
{[S Q 012]}\end{array}$ & $0 \%$ & $2 \%$ & $0 \%$ & $0 \%$ \\
\hline
\end{tabular}

The results obtained show that in the school sector and in VET the trend is very similar with small variations such as the predominance of laptops over desktop computers in VET compared to schools or a greater use of USB devices in school than in VET.

In higher education, the most used by far from the rest are laptops and desktops in the same percentage and in adult education, the use of laptops stands out above all, followed with a certain difference from desktop computers and, although there are also smartphones and the tables among the four most used their percentages are considerably lower.

Therefore, the differences in the behavior of the use of ICTs between the different educational areas are remarkable and it would be possible to inquire more about their motivation.

In the next stage of the research in which a virtual interview phase will be carried out, it would be interesting to address these differences in order to better understand the reasons that produce them.

\section{CONCLUSIONS}

This paper presents an overview of the firsts results obtained in the survey carried out with a group of Erasmus+ projects related to eLearning with key aspects in relation to their degree of success and the ICT tools used. Specifically, it reflects a very specific aspect that has to do with the use of ICT tools and devices by the students who participated in those projects.

First, the distribution of students by educational sector is analyzed, mainly highlighting School Education (Early Childhood Education, Primary Education, Secondary Education and Baccalaureate) followed by Vocational Education and Training, Higher Education and Adult Education.

Regarding the ICT tools used by the students, the predominant ones are those related to office automation management, basic skills as well as the use of network resources and platforms for collaboration, likewise other tools connected to digital educational games.

As regards to the ICT devices, both laptops and desktops stand out, and according to sectors, smartphones and tablets are also widely used.

Not only does it analyze the results obtained at a global level, but a comparison is established of how these results vary according to the educational sector in which the projects were developed.

In both cases, differences in behavior have been detected in the use of ICT tools or devices according to the educational sector, in spite of that those that stand out globally are also the most used in all sectors, although in some they are to a greater extent than in others. 
The results obtained lead to a more specific examination during the next stage of the research, which consists of an interview phase with some of the surveyed projects. In this phase, it is interesting to collect information that allows us to better understand the causes that give rise to these small variations between educational sectors, as well as to deepen the knowledge of the use that has been made of ICT with students in the projects and their impact.

In short, with the information from the survey and the interview, it will be possible to have valuable data to guide future educational projects.

\section{ACKNOWLEDGMENT}

This research work is being carried out within the University of Salamanca PhD Programme on Education in the Knowledge Society scope (http://knowledgesociety.usal.es) [24] with the mentoring and supervision of Francisco José García-Peñalvo, as well as the support available from the University of Salamanca and specifically from the GRIAL group $[25,26]$.

\section{REFERENCES}

[1] OECD. 2019. Future of education and skills 2030. OECD learning compass 2030 a series of concept notes. Retrieved from: https://www.oecd.org/education/2030project/contact/OECD_Learning_Compass_2030_Concept_Note_Seri es.pdf

[2] E. Abuabara Franco, J. Bohórquez Rivero, J. Restom Arrieta, I. Uparella Gulfo, J. Restom Tinoco, and J. Sáenz López, "Infección por SARS-COV-2 y enfermedad COVID-19: revisión literaria," Revista Científica Salud Uninorte, vol. 36, no. 1, pp. 196-230, 2020, doi: 10.14482/sun.36.1.616.211

[3] F. J. García-Peñalvo, "Digital Transformation in the Universities Implications of the COVID-19 Pandemic," Education in the Knowledge Society, vol. 22, 2021, Art no. e25465, doi: 10.14201/eks.25465.

[4] J. Cabero-Almenara and C. Llorente-Cejudo, "Covid-19: radical transformation of digitization in university institutions," Campus Virtuales, vol. 9, no. 2, pp. 25-34, 2020

[5] F. J. García-Peñalvo and A. Corell. 2020. La COVID-19; ¿enzima de la transformación digital de la docencia o reflejo de una crisis metodológica y competencial en la educación superior? Campus Virtuales 9, 2.

[6] F. J. García-Peñalvo, A. Corell, V. Abella-Garcia, and M. Grande. 2020. La evaluación online en la educaciôn,superior en tiempos de la COVID-19. Education in the Knowledge Society 21. DOI:10.14201/eks.23013.

[7] OECD. 2020. Lessons for Education from COVID-19: A Policy Maker's Handbook for More Resilient Systems, OECD Publishing, Paris, https://doi.org/10.1787/0a530888-en

[8] UE. 2021. Unión Europea. Erasmus+. Retrieved from: https://ec.europa.eu/programmes/erasmus-plus/node_es

[9] UE. 2021. Unión Europea. Erasmus+ Programme Guide. Retrieved from: https://ec.europa.eu/programmes/erasmusplus/resources/programme-guide_en

[10] UE. 2021. Erasmus+ Projects Results Platform. Retrieved from: https:/ec.europa.eu/programmes/erasmus- plus/projects/

[11] M.G. Alonso de Castro, F. J. García-Peñalvo. 2020. Methodological guide for the successful use of digital technologies in edu- cation: Improvement of learning through European educational projects. In Eighth International Conference on Technological Ecosystems for Enhancing Multiculturality (TEEM'20), October 21-23, 2020, Salamanca, Spain. ACM, New York, NY, USA, 7 pages. https://doi.org/10.1145/3434780.3436549

[12] M.G. Alonso de Castro, F. J. García-Peñalvo. 2020. Overview of European educational projects on eLearning and related methodologies: Data from Erasmus+ Project Results Platform. In Eighth International Conference on Technological Ecosystems for Enhancing Multiculturality (TEEM'20), October 21-23, 2020, Salamanca, Spain. ACM, New York, NY, USA, 8 pages. https://doi.org/10.1145/3434780.3436550

[13] M. G. Alonso de Castro and F. J. García-Peñalvo. 2021. Erasmus+ Educational Projects on eLearning and Related Methodologies: Data From Erasmus+ Project Results Platform. In F. J. Garcia-Peñalvo (Ed.), Information Technology Trends for a Global and Interdisciplinary Research Community (pp. 111-133). IGI Global. http://doi:10.4018/978-1-7998-4156-2.ch006

[14] F. J. García-Peñalvo and A. M. Seoane-Pardo, "Una revisión actualizada del concepto de eLearning. Décimo Aniversario," Education in the Knowledge Society, vol. 16, no. 1, pp. 119-144, 2015, doi: 10.14201/eks2015161119144.

[15] E. Crisol-Moya, L. Herrera-Nieves, and R. Montes-Soldado, "Educación virtual para todos: una revisión sistemática," Education in the Knowledge Society, vol. 21, 2020, Art no. 15, doi: $10.14201 /$ eks. 20327

[16] A. García Holgado, S. Marcos Pablos, R. Therón and F. J. García Peñalvo. 2019. Technological ecosystems in the health sector: A mapping study of European research projects. Journal of Medical Systems, vol. 43, art. 100, 2019. DOI: http: //doi.org/10.1007/s10916019-1241-5.

[17] A. García Holgado, S. Marcos Pablos and F. J. García-Peñalvo. 2020. Guidelines for performing Systematic Research Projects Reviews. International Journal of Interactive Multimedia and Artificial Intelligence, 6(2), 136-144. DOI: http: //doi.org/10.9781/ijimai.2020.05.005

[18] J. Meneses, D. Rodríguez-Gómez. 2011. El cuestionario y la entrevista. Barcelona: Universitat Oberta de Catalunya. https:/femrecerca.cat/meneses/publication/cuestionario-entrevista

[19] L. Fernández Núñez, L. 2007. ¿Cómo se elabora un cuestionario?. Butlletí LaRecerca. Retrieved from: de: http://www.ub.edu/ice/recerca/pdf/ficha8-cast.pdf

[20] F. García Alcaraz, A. Alfaro Espín, A. Hernández Martínez, M. Molina Alarcón. 2006. Diseño de Cuestionarios para la recogida de información: metodología y limitaciones. Revista Clínica de Medicina de Familia [en linea]. 2006, 1(5), 232-236. ISSN: 1699-695X. Retrieved

https://www.redalyc.org/articulo.oa?id=169617616006

[21] J. Fraillon, J. Ainley, W. Schulz, D. Duckworth and R. Friedman. 2019. Preparing for Life in a Digital World. The IEA International Computer and Information Literacy Study International report. Springer. Retrieved from https:/www.springer.com/gp/book/9783030387808

[22] J. Bertling, et al. 2020. A tool to capture learning experiences during Covid-19: The PISA Global Crises Questionnaire Module, OECD Education Working Papers, No. 232, OECD Publishing, Paris, https://doi.org/10.1787/9988df4e-en.

[23] M. G. Alonso De Castro. 2014. Educational projects based on mobile learning. Education in the Knowledge Society 15, 1, 10-19. https://doi.org/10.14201/eks.11650

[24] F. J. García-Peñalvo, "Education in knowledge society: A new PhD programme approach," in Proceedings of the First International Conference on Technological Ecosystems for Enhancing Multiculturality (TEEM'13) (Salamanca, Spain, November 14-15, 2013), F. J. García-Peñalvo Ed., (ACM International Conference Proceeding Series (ICPS). New York, NY, USA: ACM, 2013, pp. 575577.

[25] F. J. García Peñalvo, M.J. Rodríguez Conde, R. Therón, A. García Holgado, F.Martínez Abad and A. Benito Santos. 2019. Grupo GRIAL. IE Comunicaciones.Revista Iberoamericana de Informática Educativa (30), 3348.

[26] Grupo GRIAL. 2019. Producción Cientíca del Grupo GRIAL de 2011 a 2019(GRIALTR2019010). Salamanca, España: Grupo GRIAL, Universidad de Sala-manca. Retrieved from https://repositorio.grial.eu/bitstream/grial/1624/1/GRIAL-TR-2019010.pdf 